\title{
RECURRENT PATTERNS OF SEMANTIC CHANGE. EVIDENCE FROM GLOBAL ETYMOLOGIES
}

\section{Kozlova T. O.}

\section{INTRODUCTION}

Semantic laws have been a widely discussed issue since the discovery of Grimm's laws. Having started with the descriptions of individual lexical items, comparative linguists went on to deal with the typology of semantic derivations, systemic modifications in various word groupings ${ }^{1}$, and regular meaning changes. This was conductive to understanding semantic laws, i.e. rules referring to similarities of meaning shifts in semantically close expressions found in languages with different degree of genetic relatedness ${ }^{2}$. Etymologists considered typical semantic changes to question word origins and reconstruct protomeanings ${ }^{3}$. Cognitive linguists revealed the significance of such general mechanisms of semantic change as metonymy and metaphor in structuring our experience ${ }^{4}$. They also contributed to diachronic semantics by proving the efficiency of prototypicality and family-resemblance principles in semasiological changes ${ }^{5}$.

This study intends to examine the directionality of semantic changes accompanying the diversification of the 14 Borean etymons meaning 'shine'. Another objective is to see whether it is possible to establish any patterns in the semantic changes discovered in the global etymologies.

${ }^{1}$ Boomfield L. Language. Delhi : Motilal Banarsidass Publishers, 1996. P. 426-440. Ullmann S. Semantics. Current Trends in linguistics. Vol. 9: Linguistics in Western Europe. Th. A. Sebeok, Haugen E., Winter W. (Eds.). The Hague, Paris : Mouton, 1972. P. 343-394.

${ }^{2}$ Campbell l. Historical Linguistics: An Introduction. Cambridge, Massachusetts : MIT Press, 2004. P. 269-272. Koptjevskaja-Tamm M. Approaching Lexical Typology. From Polysemy to Semantic Change: Towards a Typology of Lexical Semantic Associations. Vanhove M. (Ed.). Amsterdam / Philadelphia : John Benjamins, 2008. P. 3-54. Sweetser E. From Etymology to Pragmatics: Metaphorical and Cultural Aspects of Semantic Structure. Cambridge: Cambridge University Press, 1998. P. 28-45. Traugott E. C., Dasher R. B. Regularity in semantic change. Cambridge : Cambridge University Press, 2004. 341 p.

${ }_{3}$ Urban M. Lexical Semantic change and semantic reconstruction. The Routledge Handbook of Historical Linguistics. Bowern C., Evans B. (Eds.). Abingdon : Routledge, 2015. P. 374-392.

${ }^{4}$ Koch P. Lexical typology from a cognitive and linguistic point of view. Language Typology and Language Universals. An International Handbook. Vol. 2. Haspelmath M., König E., Oesterricher W., Rible W. (Eds.). Berlin, New York : De Gruyter, 2001. P.1142-1178. Lakoff G., Johnson M. Metaphors We Live By. Chicago, London : University of Chicago Press, 1980. 256 p. 1997. 207 p.

${ }^{5}$ Geeraerts D. Diachronic Prototype Semantics: A Contribution to Historical Lexicology. Oxford : Clarendon Press, 
The reconstructed roots and their continuants were selected from the etymological database ${ }^{6}$, historical, bi- and monolingual dictionaries. The cognates derived from the etymons in question were interpreted by the comparative, component and cognitive analysis methods.

The paper is structured as follows. In Section 1, we will discuss two theoretical issues. The first one concerns terms applied to similar semantic changes that occur in languages distanced chronologically, geographically, and typologically. The second one considers the transparency of semantic ties established between archetypes (i.e. archaic etymons) and their reflexes in daughter branches. In Section 2, we will deal more fully with the diversification of particular proto-etymons to trace the regularity and directionality of their semantic reflexes.

\section{Theoretical issues of establishing semantic laws}

There are a variety of terms that can be used to refer to the similarity of diachronic changes in meaning. Among most widely employed terms are semantic universals, semantic rules, semantic regularities, and semantic laws.

Some historical linguists exploit the term semantic universal just to deal with the phenomenon of language change on a universal basis. Given that semantic factors are significant for language typology and, consequently, for language change, they believe there are semantic changes that are not isolated to a particular set of languages. In other words, although languages develop into different types, they exhibit similar semantic changes. If, in P. Durst-Anderson's terms, languages demonstrate "types [and] supertypes"7, it seems methodologically sound to use the term semantic universals. However, as cross-linguistic studies supported a rather vexing anthropological doctrine of "psychic unity of humankind", semantic universals would rather confirm with "the notion of semantic primitives (or semantic primes)",9 , inherently more intelligible and semantically more basic concepts, that is "a universal set of fundamental human concepts" 10 . When considered in this perspective, the term semantic universals is less attractive than other terms.

\footnotetext{
${ }^{6}$ Sratostin S., Starosin G. The Tower of Babel. An Etymological Database. 1998-2013. URL: http://starling.rinet.ru (retrieved May 14, 2014).

${ }^{7}$ Durst-Andersen P. Linguistic Supertypes: A Cognitive-Semiotic Theory of Human Communication. Berlin / New York : Walter de Gruyter, 2011. P. 167.

${ }^{8}$ Shore B. Culture in Mind: Cognition, Culture, and the Problem of Meaning. Oxford: Oxford University Press, 1998. P. 15.

${ }_{9}^{9}$ Wierzbicka A. Semantics : Primes and Universals : Primes and Universals. Oxford : Oxford University Press, 1996. P. 15.

${ }^{10}$ Ibid. P. 10, 13.
} 
Scientists who prefer to use semantic rules should keep in mind that 'the semantic rules criterion' is widely applied in formal semantic theories to discuss conditions for coherence and meaningfulness of words in sentences in contrast to the rules of $\operatorname{syntax}^{11}$. For this reason, the application of the term to regular semantic changes should be avoided.

The term semantic regularity seems most popular in the Englishspeaking publications on diachronic changes. However, in some interdisciplinary studies they rightly remark that whatever regularities are found in languages, they are not restricted to linguistic items. J. Margolis supports Ziff's thesis on semantic regularities and quotes him on that they are "to be found in connection with $<\ldots>$ both linguistic elements and other things, e.g. utterances and situations, or $<\ldots>$ phrases and persons, as well as $<\ldots>$ utterances and utterances" ${ }^{\prime 2}$. From this postulate it can be concluded that a semantic regularity is interpreted "as an association between an utterance type and a condition, an association which usually occurs without giving rise to bizarre or “deviant” utterances" ${ }^{13}$, such as saying Hello! when someone leaves.

The term semantic law/s was introduced and used by European semanticists in the first half of the $20^{\text {th }}$ century. As S. Ullman claims, "the quest for 'laws' has always been one of the principal preoccupations" 14 for comparative linguists. It is recognized that universal laws of thought should be reflected in the meaning formation and change ${ }^{15}$. Nevertheless, little advancement has been made in the research of semantic development apart from discovering about social and psychological reasons of semantic changes, as well as their mechanisms and how meanings were generalised in archaic languages. Historical linguists would rather prefer to speak modestly about general tendencies, parallel semantic development, systemic semantic changes that involve, for instance, more metaphoric transfers from human sphere than into it, historical sequence of synaesthetic metaphors, etc. Despite unpredictability of meaning change, especially in language contact situations, some historical directionality can be established: space $>$ time, temporal $>$ conditional, body part $>$ space $^{16}$.

\footnotetext{
${ }^{11}$ Swineburne Th. The Coherence of Theism. Oxford : Clarendon Press, 1993. P. 30-38. Lyons J. Semantics. Cambridge : Cambridge University Press, 1977. P. 411-413.

${ }_{12}$ Margolis J. Culture and Cultural Entities: Toward a New Unity of Science. Berlin, New York : Springer Science \& Business Media, B.V. 2013. P. 149.

${ }^{13}$ Quoted in: Germain C. The Concept of Situation in Linguistics. Ottawa : University of Ottawa Press, 1979 P. 48.

${ }^{14}$ Ullmann S. Semantics. Current Trends in linguistics. Vol. 9: Linguistics in Western Europe. Sebeok Th. A., Haugen E., Winter W. (Eds.). The Hague, Paris : Mouton, 1972. P. 365.

${ }^{15}$ McMahon A. M. S. Understanding Language Change. Cambridge : Cambridge University Press, 1994. P. 176.

16 Traugott E. C., Dasher R. B. Regularity in semantic change. Cambridge : Cambridge University Press, 2004. P. $41,43$.
} 
Linguists remain undeterred in their search of semantic laws, and the term has not been abandoned. V. Levitsky, a leading authority in etymology, historical semantics and phonosemantics in Ukraine, disproved the statement that "there are no laws in semantics"17 by crosslinguistic data collected from Germanic and some other Indo-European languages. V. Levitsky moved towards the goal of discovering semantic laws and offered 40 statistically confirmed semantic change patterns ${ }^{18}$ in addition to 254 systemic semantic ties in the Germanic languages ${ }^{19}$. It is remarkable that $\mathrm{V}$. Levitsky consistently referred to semantic laws ${ }^{20}$ in parallel with other terms (regular semantic changes, typical semantic changes $^{21}$, semantic universals ${ }^{22}$ ).

We see, therefore, that the terminology used to discuss systemic semantic changes can be employed in a variety of ways and interfaces with many other aspects of language use and formation. On the other hand, the terms are converging on temporal and atemporal, panchronic and cognitive perspectives from which diachronic semantic derivations can be viewed. For that reason, the choice of the term is determined by the preference and purposes of a researcher. Leaving the discussion on the legitimacy of semantic law aside, we will hereafter employ it.

In addition to terminological issues, it is necessary to discuss the problems of the archetype reconstruction. These will only be briefly summarised from the point of view of the transparency of historical semantic ties. To establish semantic laws, it is important to look into the long-term data and decrease limitations in the number of languages included into the analysis. This task can be realised by covering a stock, i.e. the largest possible grouping of languages with the common reconstructed ancestor. In view of the fact that archaic etymons are hypothetical versions and do not have any attestations in written sources, diachronic semantic ties may be rather vague. That creates a problem of methodological importance. When it comes to the reconstruction of meaning or a historical sequence of meanings, linguists do not have such strict criteria as they do for phonetic reconstruction and have to rely upon different degrees of semantic similarity.

${ }^{17}$ Quoted in: Ullmann S. Semantics. Current Trends in linguistics. Vol. 9: Linguistics in Western Europe. Sebeok Th. A., Haugen E., Winter W. (Eds.). The Hague, Paris : Mouton, 1972. P. 366.

18 Левицкий В. В. Семасиология. Винница : Нова книга. С. 402.

19 Левицкий В. В. Этимологический словарь германских языков. Том II. Винница : Нова кныга, 2010. С. 336-342.

20 Левицкий В. В. Семасиология. Винница : Нова книга, 2006. С. 15, 17, 18, 26, 34, 44, 330, 400-402. Левицкий В. В. Этимологический словарь германских языков. Том І. Винница : Нова кныга, 2010. С. 25.

${ }^{21}$ Ibid.

22 Левицкий В. В. Этимологический словарь германских языков. Том II. Винница : Нова кныга, 2010. С. 336. 
The semantic ties between etymons and their continuants should be considered transparent on the conditions leading to complete or partial equivalence of meanings in various reflexes.

Complete equivalence among the meanings can be instanced by the continuants of PIE *nas- "nose": OInd. nấsika "nostril, nose", Av. nāh-, nāyhan- "nose”, Lat. nāris "nostril”, OFris. nōsi, OHG nasa "nose”, OSw. nōs "snout", ON nos "nostril, nose; rock", OE nasu, Prus. nozy, Lith. nósis "nose”, OSl. ноздри, Alb. hundë "nose”, Hitt. titita "nose”, etc. The semantic isoglosses are quite predictable as they are shaped in the directions of WHOLE ('nose') > PART ('nostril'), HUMAN ('nose') > NON-HUMAN > ANIMAL ('snout'), ANIMATE ('smth that sticks out from the face') > INANIMATE ('smth that sticks out of the ground'). Because such diachronic changes mostly result in compatible meanings and small semantic distances between an archetype and its reflexes, they enable "straightforward semantic reconstruction", 23 and interpretation of regularities in semantic change.

In spite of transparent semantic shifts, it may still be problematic to see the direction of modification, especially when we have to deal with fuzzy concepts. As we know, a fuzzy concept involves the intersection of features and the absence of clear-cut boundaries between notions. Consider 'the lower part of the face' for the notions 'cheek' and 'jaw':

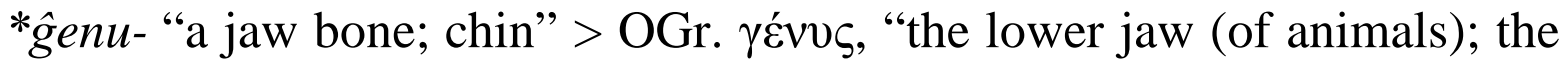
lower part of the face (chin, cheeks, lips); snout; cheek, etc"; Skr. hanuh; Av. zanu- "chin"; Arm. cnaut "chin; cheek"; Toch. A śanwehm (du.) "lower jaw ”. L. Bloomfield suggested the order 'jaw' > 'chin', 'cheek' for Latin, French and Italian $^{24}$.

Partial equivalence demonstrates the formation of more diversified semantic isoglosses. Although the meanings are closely associated, the direction of the semantic change is hard to predict: PIE *akw $\bar{a}$ - "water" LIQUID > OInd. kām "water"; FLOW (OHG aha, Ger. Ache "river; current”); CHANNEL OF FLOW (Lat. aqua "water; gutter”); FROZEN LIQUID (Alb. akull "frozen water"); TO TAKE LIQUID (Toch. A, Toch. B yok-tsi "to drink", Hitt. e-ku-uz-zi (ekuzi) "he/she drinks"); AREA OF WATER (OE $\bar{e} a$, Goth. aha "water; the body of water"); SMTH SUROUNDED BY WATER, SUBJECT TO FLOODING (Sw. $\ddot{o}$ "island"; OIcl. ey "island; meadow"); MYTHOLOGICAL HERO (OIcl. Ágir "the God of the sea, Ocean”). Becoming more vague, semantic ties

\footnotetext{
${ }^{23}$ Gell-Mann M., Peiros I., Starostin G. Distant Language Relationship: The Current Perspective. Journal of Language relationship. 2009. \# 1. P. 13-30.

${ }^{24}$ Boomfield L. Language. Delhi : Motilal Banarsidass Publishers, 1996. P. 427.
} 
between the archetype and its continuants gradually result in incompatibility of meanings.

As semantic laws in such cases are not easily established, the challenge for a researcher is to discover links between etymons and reflexes. It seems that a cognitive approach will provide more interpretive power. The examples below demonstrate that metonymic shifts, perhaps even more basic for human cognition than metaphoric projections, abound in the history of words. The directionality of meaning change is determined by mental projections taking place in the same experiential domain whereby the target is interpreted in terms of the source (the whole-for-part or the part-for-whole mappings). The whole-for-part / part-for-whole associations are realised in various semantic patterns arising when the knowledge about the whole "activates" 25 the knowledge about the parts and vice versa:

- partonymy (the holonym PIE *krep-/*krp- "body" > the holonym Lat. corpus "body; flesh" and the meronyms Lat. corpusculum "a small body; fetus"; PGmc. *href-iz "belly; stomach" > OHG href, OE hrif, Du. rif, OFris. href, hrif "belly”; ME mid-(h)rif, OFris. mid-ref "diaphragm”, i.e. 'inside the body');

- hyperonymy (the hyperonym PIE *er-/*or- "a large bird" > the hyponyms PGmc. *ara(n)- "eagle” > OHG aro, Ger. Aar; ON arn-, Sw. örn; OE earn, ME erne; Goth. ara, Du. arend "eagle"; Arm. oror "seagull”; OGr. ópvis "bird; cock”, Gr. ó $\rho v \imath \theta \alpha$ "hen”;

- co-hyponymy (PIE * ghan-s- "goose" > OE ganot, gannet, ME gannet "a kind of sea-bird; cormorant”, OE ganra, gandra, gander, ME gandor "gander”; OIr. géis, geissi "swan”; OInd. hamsá-h, haìsī "goose; swan").

Meaning incongruence between etymons and their reflexes will stand in the way of establishing change sequence. For example, the semantic ties between PIE *akw $\bar{a}$ - "water; river", Lat. aquila "eagle" and aquilo "northern wind" have lost motivation. Whatever etymological version is accepted, it puts a researcher on shaky ground: 'water' $>$ 'a source of water' > "where eagles drink" or 'water ' > 'smth that brings water' > 'northern wind'. To discover the order of diachronic distancing from the archetype, it is required to apply a set of criteria: the productivity of isoglosses; degree of genetic relatedness in languages; contact-induced influence; "étalon language" 26 , which is generally understood as a standard against other languages that are evaluated and compared.

\footnotetext{
${ }^{25}$ Kovecsec Z., Radden G. Metonymy: Developing a Cognitive Linguistic View. Cognitive linguistics. 1998. 9 (1). P. 39.

${ }^{26}$ Trask R. L. Dictionary of Historical and Comparative Linguistics. Chicago, London : Fitzroy Dearborn Publishers, 2000. P. 109.
} 
Recurrent patterns of semantic change may turn efficient in establishing language affiliations, discovering semantic universals that go beyond any type of genetic, typological and areal relatedness.

\section{Borean roots meaning 'shine' and recurrent patterns of semantic change}

The starting point for the research was the Borean super-family hypothesis by S. Starostin, who proposed deep relationship between Nostratic (Eurasiatic and Afroasiatic) and Dené-Daic (Dené-Caucasian and Austric) macrofamilies. This model, although a speculative one, covers most languages of the northern hemisphere with deep ties to their common predecessor - the Upper Paleolithic Borean proto-language dated back to $50.000-45.000$ years ago ${ }^{27}$. It is hypothesised that Amerindian family may also be related to Borean ${ }^{28}$.

The larger the number of languages we consider, the more reliable conclusions we therefore can make about semantic laws. It is especially instructive to turn to reconstructed languages, because "if related, they provide data from earlier times when they were far more alike than their modern-day descendants” ${ }^{29}$ and more transparently manifested universal laws of human thought.

The analysis of 14 reconstructed Borean roots meaning "to shine" revealed six features widely represented across macrofamilies: 'lightradiant object', 'light; bright', 'white; pale', 'day, morn, daylight', 'see, appear', 'happy, merry, bright, nice, desire'.

The greatest degree of semantic regularity has been found for the semantic feature 'light-radiant object'. The continuous isogloss embraces all the macrofamilies in question linking them to all the etymons analised. For instance, Borean *HVLV "light; shine" is continued the Nostratic languages (Eurasiatic *HVLV "light; shine" > Altaic, Evn. ilān "moon", Ch.-K. *hъlhъ "sun" and Afroasiatic > Semitic, Arab hiläl- "new moon"); as well in Amerindian (*ali "sun”), and African (Bantu *-yédì “moon”). Semantic reflexes follow the path 'shine > source of light; smth radiating light' and develop such meanings as "moon”, "sun”, "star”, "constellation”.

The change in the direction of "lightening", "fire”, "flame”, "coal” is less spread than "heavenly body". The features 'artificial source of light'

\footnotetext{
${ }^{27}$ Pereltsvaig A. Languages of the Worlds: An Introduction. Cambridge : Cambridge University Press, 2012. P. 227.

${ }^{28}$ Peregrine P. N., Peiros L, Feldman M. W. Ancient Human Migrations: A Multidisciplinary Approach. Michigan : University of Utah Press, 2009. P. XI.

${ }^{29}$ Renfrew C., Nettle D. Nostratic: Examining a Linguistic Macrofamily. Cambridge : McDonald Institute for Archaeological Research, University of Cambridge, 1999. P. 111.
} 
("torch") or 'sources radiating small amount of light' ("ray", amber") are better traceable in smaller genetic groups when the extensional of the concept grows. Cf.: Borean ${ }^{*} C V L V$ "shine" > Austric *sila "radiation of light" > *qusila "lightening"; PIE *leuk- "shine" > PGmc. *leuh-/lauh"light”, Goth. lauhmuni "lightening”, Lat. L(o)ucetius "epithet for Jupiter, i.e. the one who brings light".

On a closer inspection we can see that with the growing application, the direction of semantic change is hard to predict because it recurs through a far greater number of target domains as in the reflexes of PIE *leuk- "shine": HEAVENLY BODY - OIr. luan, Arm. lusin "moon"; ANIMAL - Ger. Luhs "lynx, i.e. the one with sparkling eyes"; OIcl. lýsa “merling, or whiting, a kind of fish”, BODY OF WATER - OIcl. leygr "fire; sea, i.e. that which is sparkling", A SMALL ROUND AREA - OIcl. ljóri "a hole on the roof, i.e. a light spot"; AN AREA OF LAND - OE léah "meadow, field, grove", etc. It is no surprise that irregularity of meaning change grows as cognates distance from the common core: PIE *leuk- "shine" > 'THAT IS SHINING, WHITE' 'OInd. rúśant"light, white" > Ger. Luhs, Lith. lúšis, Rus. pblcb, Arm. lusanun-, Lat. lynx "lynx", > Rus. лысысый "bald". The irregular change, such as 'bald', therefore, is to be seen as a deviation from a set of related meanings. One may argue that language strives for economy and avoids unnecessary, costly modification, or that such divergences are accidental. Nevertheless, irregular changes may be very important when they are triggered by culture-specific factors, pragmatic and cognitive preferences of speakers.

The cross-linguistic spread will be different when we consider the recursion of other features 'white, pale', 'day, daylight, morn', 'see, appear', 'happy, glad, merry, triumphal'. On the one hand, these lexicosemantic shifts do occur regularly. On the other hand, semantic development is on increasingly divergent paths. For instance, PIE * $g h e l-$ "shine" developed in the daughter branches in two directions. In Baltic and Celtic languages, the dominant trend is towards 'FULL OF LIGHT > BRIGHT WHITE' (Lith. gulbe "swan; a white cow”, báltas kaĩ̄p g. "as white as swan”, Latv. gùlbis "swan; a white cow”; OIr. gel "bright; shining; white"), whereas Greek and Indic isoglosses go in the opposite direction 'LESS COLOUR > WHITE, PALE' (OGr. $\chi \lambda \omega \rho o ́ \varsigma$ "greenish; pale; light”, OInd. hári-, Skr. hári "pale, yellowish”. The isoglosses seem to intersect in Iranian: Av. zari "golden, yellowish", zairita "yellow-pale".

Less regularity should be assigned to a higher degree of subjectivity required in order to cognise such domains as colour, daylight, perception or 
mental activity, emotion and attitude, evaluation. Understanding these phenomena calls for inference and focusing on the attributed traits of denotata. Dealing with sources of light (like heavenly bodies and artifacts), we first and foremost interact with our experience. However, optical effects of light and brightness interact with our emotions rather than experience, alter our moods and emotional states. Hence, such things are "related not entirely to the natural world, but also to the cultural contex" ${ }^{\text {, }}$. For this reason, semantic changes following the direction of 'colour', 'time', 'seeing', 'happiness, gladness' are more culture-specific, because they are shaped by our emotional experience and ethnic worldview.

Let us consider, for instance, the development of Eurasian *belV "shine" in the Altaic languages. The Mongolic isoglosses are indicative of the change towards 'SHINE' > 'MAKE SMB UNABLE SEE OR UNDERSTAND' - PAlt. *bè̀ló "pale” > PMong. *balaj "blind; dark” > Dag. balia "unclear; obscure”, balie "blind”; Ord. bal̄̈ “stupid, pointless”. The Manchu-Tungus isoglosses correlated with 'SHINE > LIGHTEN, WHITEN, REDUCE THE INTENSIVITY OF COLOUR' - PTung. *beli "pale; turn white, pale" > Even. beli-). In contrast, the Korean isogloss reflects the dominant semantic feature 'SHINE > LIGHT, BRIGHT; BEING BRIGHT' (PKor. *pằrk- "bright, light” > Mid.Kor. pằrk-, кор. pak-[palk-]) and accentuates the achieved state while the Japanese reflexes combine 'light' and 'transparency, clearness' to focus on the transition 'SHINE > BECOME CLEAR, LIGHT, TRANSPARENT' (PJap. *pàrá- "clear up (of sky, weather) ” > OJap . para-, Mid.Jap. fàrá-, Tokyo dial. haré-).

In sum, a semantic feature common for a macrofamily of languages tends to be more specialized and contrastive in language families and groups. It is noteworthy that differentiated semantic features are expressed by particular forms. Cf.:

$\left[\left\{\mathrm{C}_{1}\right.\right.$ VOICED $\mathrm{VC}_{2}$ SONORANT $\}+\{$ 'lose brightness / dark' $\left.\}\right]$ - *bè̀ló, *balaj, balia, balie, balä and *beli, beli-;

$\left[\left\{\mathrm{C}_{1}\right.\right.$, voiceless $\mathrm{VC}_{2}$ sonorant $\}+\{$ 'acquire brightness / light' $\left.\}\right]-$ *pằrk-, pằrk-, pak- and *pàrá-, para-, fàrá-, haré-.

In our view, such form-meaning correlations are sound symbolic. It can be evidenced by the imitative role of voiced and voiceless consonants in ideophone structures.

${ }^{30}$ Baker N., Steemers K. Daylight Design of Buildings: A Handbook for Architects and Engineers. New York : Routledge, 2014. P. 102. 
In the Mongolic and Manchu-Tungus languages, voiced labials encode 'dark colour' (Mong. baruyar “dark colour, dark complexion”, baruyj"dark; unclear; worried; gloomy, frowned (look, face)"31, Manch. algari bulgari ( alxa bulxa) "multi-coloured, spotted, variegated"32.

In Korean and Japanese, voiceless stops are structural constituents in the names of weak light, small bright flashes, or reflected light: Kor. pantchak / ppantchak "radiate light; lighten"33, palk- "light, bright, clean; morn”, ppalkah “crimson, deep-red”, palkah "bright-red”34; Jap. pachi-pachi (to) "blink"35, pika' "make a blink", pika-pika no yuka "shiny, clean floor", pika-pika no hage-atama "shiny bald head", kirarikirari "glitter",

In contrast to Altaic, the Indo-European languages employ the symbolism of vowels. In the Germanic languages, the opposition 'light dark' is realised by vocalic contrast $/ \mathrm{i}-\mathrm{u} /{ }^{37}$. To instance it, we discuss the continuants of the Borean root ${ }^{*} C V J V$ "shine" > Eurasian ${ }^{*} c$ ' aj $V$ "shine" $>\mathrm{PIE} *_{s} \hat{k} \bar{a} i-/ s \hat{k} \partial i-/ s \hat{k} \bar{l}$ " "glitter, glimmer, light reflection, wet shining; shadow" that diverge into three groups of isoglosses.

The first, and the most productive, group of isoglosses includes such semantic features as 'the presence of light' (Goth. skeirs "clear, bright", skeinan "lighten, shine", skeima "torch") or 'the absence of light' (Pers. sāya "shadow; covering, protection"; Toch. B skiyo, Latv. Seja, Alb. hē, hie "shadow").

The second, less productive, group of isoglosses embraces syncretic combination of features 'light; shadow': OInd. chāy á "shade, shadow; a reflected image; play of light or colours, lustre, light”; Skr. chāya "shadow; coolness; cover; mixture of paint, colours; interplay of light and shadows; sparkles; light, colour; Shadow, Sun's wife and Saturn's mother; the sun”38.

${ }^{31}$ Finch R. Mongolian /-gar/ and Japanese /-gar/. Evidence and Counter-Evidence: Essays in Honour of Frederik Kortlandt. Vol. 2 : General Linguistics. Lubotsky A., Schaeken J., Wiedenhof J. (Eds.). Amsterdam, New York : Rodopi, 2008. P. 135.

${ }^{32}$ Ibid. P. 138.

${ }^{33}$ Cho Y. Y. Sound Symbolism in Korean. Korean Language in Culture and Society. Sohn H. (Ed.). Honolulu : University of Hawai'i Press, 2006. P. 65.

${ }^{34}$ Finch R. Mongolian /-gar/ and Japanese /-gar/. Evidence and Counter-Evidence: Essays in Honour of Frederik Kortlandt. Vol. 2 : General Linguistics. Lubotsky A., Schaeken J., Wiedenhof J. (Eds.). Amsterdam, New York : Rodopi, 2008. P. 127.

${ }^{35}$ Dictionary of Iconic Expressions in Japanese. Vol I: A-J. Vol II: K - Z. Kakehi H., Tamori I, Schourup L with the assistance of Emmerson L. E. (Eds.). Berlin : Mouton de Gryteur, 1996. P. 869.

${ }^{36}$ Finch R. Mongolian /-gar/ and Japanese /-gar/. Evidence and Counter-Evidence: Essays in Honour of Frederik Kortlandt. Vol. 2 : General Linguistics. Lubotsky A., Schaeken J., Wiedenhof J. (Eds.). Amsterdam, New York : Rodopi, 2008. Р. 673, 929, 931.

37 Левицкий В. В. Этимологический словарь германских языков. Том І. Винница : Нова кныга, 2010. С. 472.

${ }^{38}$ Monier-Williams M. A Sanskrit-English Dictionary: Etymologically and Philologically Arranged with Special Reference to Cognate Indo-European Languages. Köln : Universität zu Köln Institut für Indologie und Tamilistik, 2012. 1333 p. URL : http://www.sanskrit-lexicon.uni-koeln.de/monier/ (retrieved September 14, 2014). 
The third group contains pairing isoglosses: Rus. сиять "radiate bright light, shine" vs Rus. сень "shadow"; OE scima "shadow, darkness", ME scimian "darken, frown; blur, blind, make misty” vs OE scíma "beauty; brightness, light", scímian "lighten; sparkle”39, where semantic oppositions are encoded with the help of vocalic contrasts $\mathrm{C}_{1} \mathbf{V}_{\mathbf{1}} \mathrm{C}$ 'light' vs $\mathrm{C}_{1} \mathbf{V}_{2} \mathrm{C}$ 'shadow; dark'. Cf.:

\author{
PGmc. PGmc. *skīm-/skim-
OIcl. skimi, skími, skíma "a \\ glimpse";
}

Ger. schimmer "weak light; glimmer; a glimpse of hope", shimmern "shimmer (of metal, water, etc.)" (ihre Augen schimmerten Feucht "her wet vs eyes shimmered”, ihr Haar schimmert rötlich "her hair is of red shade" (lit. 'shimmer'));

PGmc. *skair-/skīr-"light; bright" > Sw. skär "pink" (skärhy "tender complexion"), skir "clean, transparent" (skiret "gauze", hónung "purified honey");
PGmc. *skium/skum-/sküm- > OIcl. skuma "become dark", skúmi "shadow; twilight", skúma-skot "twilight”, skríða í skúma-skot "dark corner”, skúma "a nickname” vs (Dorleifr Porkelsson skúma ("the dark') "40 "The Dark" (a nickname of Torleif skuma Torkelsson, the Icelandic poet, c 986); Dan. skummel, skumring “twilight”;

Ger. schummern "darken” (es summert "Twilight is falling" $"$ ) ;

Sw. skymma "darken; eclipce" (mólnet skýmmer sólen 'the cloud eclipsed the sun', tấrarna skýmde blícken 'tears blurred the eyes'; skýmning "twilight, half-darkness", hălla sig i skýmundan lit. 'keep in the shade, hence "keep a low profile, hide") $)^{42}$.

\footnotetext{
${ }^{39}$ Bosworth J. An Anglo-Saxon dictionary, based on the manuscript collections of the late Joseph Bosworth (Main Volume, first edition 1898) and its Supplement (first edition 1921). Bosworth J., Toller Th. N., et. al. (Eds.); Christ S., Tichý O. (Compls.). Prague: Faculty of Arts, Charles University, 2010. URL : http://bosworth.ff.cuni.cz (retrieved September 14, 2014).

${ }^{40}$ Ross M. C. A History of Old Norse Poetry and Poetics. Cambridge, New York : DS Brewer, 2011. P. 203.

${ }^{41}$ Collins German Unabridged Dictionary. Terrell P. (Ed.). 5th ed. Glasgow : HarperCollins, 2004. 2108 p. URL : http://dictionary.reverso.net/german-english/ (retrieved September 14, 2014).

${ }_{42}$ Шведско-русский словарь. Миланова Д. Э. (Сост.). Москва : Изд-во “Советская энциклопедия”, 1973. C. $505,514,516$.
} 
The contrast /i - u/, also present in proto-forms: PGmc. *glīm- > 'LIGHT, GLITTER' OSax. glīmo “glimmering, glittering” vs Gmc. *glum > 'DARK, GLOOMY' (Norw. dial. glyma "give a gloomy look”, OIcl. glúmr “a bear”, i.e. 'gloomy'. It proves non-accidental, nonrandom form-meaning correlation. Such formations are motivated and grounded in acoustic and articulatory manipulations of speech sounds.

Apart from consonantal and vocalic sound symbolic effects, the significance of iconicity in verbalisations of 'luminocity' is evident from metathetical arrangements of archetypes. For instance, Borean $* \boldsymbol{J V} K \boldsymbol{V}$ "lighten; light" vs Borean *CVJV "radiate light, glimmer; shadow" which are continued to verbalise antithetic concepts: PIE *(S)KEWっ-) "DARK" > PGmc. *skiw-ja-, *skuww-án-, *skū-m, *sku-m-, *xü-m-a-, *xü-m-an-, *xum "shadow, shade, darkness"; PBalt. *skuñ - "gloomy, sad" vs PIE *K'WEIT- "LIGHT, WHITE; RADIATE LIGHT” > PGmc. *xwìta-, *xwit(t)a-, *xwaitī, *xwaitia-z, *xwītia-z "white”; PBalt. *čwert-, *čwit-,

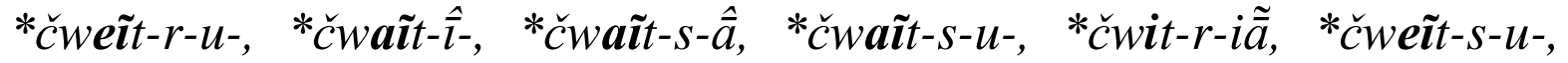
*čwaît-s-t-a- "shine".

It can be stated with certainty that semantic laws are realised differently in various language groupings. The directionality and regularity of diachronic semantic change is determined by numerous cultural and cognitive factors including salience of the cognised features, semiotic and sign-manipulation competence. Even though the analised units are taken out of context, they transparently demonstrate that parallel or congruent semantic development is not sustained along the whole genetic trajectory. The distance between the paths of semantic change varies and grows with distancing from the archetype, or common core. It appears that semantic changes are more predictable at super-family level whereas language families and groups exhibit more specificity in historical semantic variation. It seems, therefore, that a popular methodological approach to study semantic laws on a limited number of languages ${ }^{43}$ needs revision.

\section{CONCLUSIONS}

Recurrent patterns of semantic change behave differently in various language phyla. The highest degree of similarity is found in global, i.e. super-family, spread of semantic features. In smaller groupings, like super-families, families, and other branches, divergent processes occur

43 Левицкий В. В. Семасиология. Винница : Нова кныга, 2006. С. 401. Traugott E. С., Dasher R. B. Regularity in semantic change. Cambridge : Cambridge University Press, 2004. P. 48. 
through geographical, cultural and historical separation and lead to gradual involvement of innovative features. The reflexes of proto-etymons undergo changes to satisfy speakers' cognitive, semiotic, and communicative needs.

The results indicated that such semantic changes as 'shine > light', 'shine' > 'a heavenly body' (sun, moon, star, constellation), 'shine > 'bright' and 'shine' > 'look' are global. The isoglosses 'shine' $>$ 'a natural source of light', and 'shine' > 'an artifact radiating light' exhibited more specificity in various genetic groupings. The isoglosses 'shine $>$ pale, light in colour', 'shine > morn, day, twilight' turned to be less productive. Languages showed the highest degree of diversification in pragmatic isoglosses, such as 'shine > nice, happy, gay' and 'shine > bald'. Semantic changes that occur globally embrace metonymic shifts within the luminosity domain due to universality of human experience with lightemitting objects and perception of light radiation. Treatment of brightness is determined by cultural properties of observers, the availability of the source of light radiation, the perception and cognitive perspectives. Therefore, semantic changes 'shine' > 'colour', 'shine' > 'time', 'shine' > 'emotion, mood' were motivated by more subjective jundgements and exhibited specific realisations in different genetic groups.

The findings also suggest that proto-roots were highly referential, hence efficient in representing a small number of basic concepts. In their historical development, the proto-concepts followed the elaboration by metonymic and metaphoric extensions that brought out hidden meanings reinterpreted by sign-makers.

Overall, although regular semantic changes are found in different phylogenetic groups, their specificity increases from super-family to macro-family, family, and language group, i.e. with the distance from the common ancestor or core.

As semantic reconstruction influences the scientifically established order of changes, it requires a more elaborate procedure considering the specificity of proto-languages, a highly motivated nature of archetypes, their iconic potential and efficiency of mimetic expression in archaic languages.

The results demonstrated the significance of consonantal and vocalic symbolism in representation of 'luminosity' oppositions. Being articulatory strong, voiceless consonants are employed to iconically represent 'intensive emission of light, brightness' in contrast to articulatory weak voiced consonants which are present in words denoting 
'weak emission of light, half-darkness' in the Altaic languages. Another strategy of encoding the opposition 'light - dark' exploits the symbolic potential of vowels. Thus, the Indo-European languages tend to appeal to front vowels, pronounced by positioning the highest point of the tongue in the front of the mouth, to encode 'light', while back vowels, produced by positioning the highest point of the tongue relatively back in the mouth, are used in naming 'half-darkness'. These facts prove the significance of ideophonia, automimesis and allomimesis in conceptualisation and verbalisation of 'luminosity'.

Further research into semantic regularities in different language phyla may broaden the perspective on the similarities and differences in the human experience across time and space.

\section{SUMMARY}

The purpose of this study was to examine the directionality of semantic changes accompanying the diversification of the 14 Borean etymons meaning 'shine' and establish recurrent patterns in the semantic changes discovered in the global etymologies. The results supported the hypothesis that recurrent patterns of semantic change behave differently in various language phyla. The highest degree of similarity is found in global, i.e. super-family, spread of semantic features. In smaller groupings, like super-families, families, and other branches, divergent processes occur through geographical, cultural and historical separation and lead to gradual involvement of innovative features. The findings demonstrated the significance of consonantal and vocalic symbolism in encoding 'luminosity' oppositions. Another important conclusion was that protoroots were highly referential and efficient in representing a small number of basic concepts. In their historical development, the proto-concepts followed the elaboration by metonymic and metaphoric extensions that brought out hidden meanings reinterpreted by sign-makers.

\section{REFERENCES}

1. Левицкий В. В. Семасиология. Винница : Нова кныга, 2006. $512 \mathrm{c}$.

2. Левицкий В. В. Этимологический словарь германских языков. Том I. Винница : Нова кныга, 2010. 616 с.

3. Левицкий В. В. Этимологический словарь германских языков. Том II. Винница : Нова кныга, 2010. 368 с. 
4. Шведско-русский словарь. Миланова Д. Э. (Сост.). Москва : Изд-во “Советская энциклопедия”, 1973. 760 с.

5. Baker N., Steemers K. Daylight Design of Buildings: A Handbook for Architects and Engineers. New York : Routledge, 2014. 260 p.

6. Boomfield L. Language. Delhi : Motilal Banarsidass Publishers, 1996. 576 p.

7. Bosworth J. An Anglo-Saxon dictionary, based on the manuscript collections of the late Joseph Bosworth (Main Volume, first edition 1898) and its Supplement (first edition 1921). Bosworth J., Toller Th. N., et. al. (Eds.); Christ S., Tichý O. (Compls.). Prague : Faculty of Arts, Charles University, 2010. URL : http://bosworth.ff.cuni.cz (retrieved September 14, 2014).

8. Cho Y. Y. Sound Symbolism in Korean. Korean Language in Culture and Society. Sohn H. (Ed.). Honolulu : University of Hawai'i Press, 2006. P. 64-73.

9. Collins German Unabridged Dictionary. Terrell P. (Ed.). 5th ed. Glasgow : HarperCollins, 2004. 2108 p. URL : http://dictionary. reverso.net/german-english/ (retrieved September 14, 2014).

10. Dictionary of Iconic Expressions in Japanese. Vol I: A-J. Vol II: K-Z. Kakehi H., Tamori I, Schourup L. with the assistance of Emmerson L. E. (Eds.). Berlin : Mouton de Gryteur, 1996. 1468 p.

11. Durst-Andersen P. Linguistic Supertypes: A CognitiveSemiotic Theory of Human Communication. New York, Berlin : Walter de Gruyter, 2011. 326 p.

12. Finch R. Mongolian /-gar/ and Japanese /-gar/. Evidence and Counter-Evidence: Essays in Honour of Frederik Kortlandt. Vol. 2 : General Linguistics. Lubotsky A., Schaeken J., Wiedenhof J. (Eds.). Amsterdam, New York : Rodopi, 2008. P. 113-150.

13. Geeraerts D. Diachronic Prototype Semantics: A Contribution to Historical Lexicology. Oxford : Clarendon Press, 1997. 207 p.

14. Gell-Mann M., Peiros I., Starostin G. Distant Language Relationship: The Current Perspective. Journal of Language relationship. 2009. \# 1. P. 13-30.

15. Germain C. The Concept of Situation in Linguistics. Ottawa : University of Ottawa Press, 1979133 p.

16. Koch P. Lexical typology from a cognitive and linguistic point of view. Language Typology and Language Universals. An International Handbook. Vol. 2. Haspelmath M., König E., Oesterricher W., Rible W. (Eds.). Berlin, New York : De Gruyter, 2001. P .1142-1178. 
17. Koptjevskaja-Tamm M. Approaching Lexical Typology. From Polysemy to Semantic Change: Towards a Typology of Lexical Semantic Associations. Vanhove M. (Ed.). Amsterdam / Philadelphia : John Benjamins, 2008. P. 3-54.

18. Kovecsec Z., Radden G. Metonymy: Developing a Cognitive Linguistic View. Cognitive linguistics. 1998.9 (1). P. 37-77.

19. Lakoff G., Johnson M. Metaphors We Live By. Chicago, London : University of Chicago Press, 1980. 256 p.

20. Lyons J. Semantics. Cambridge : Cambridge University Press, 1977. $897 \mathrm{p}$.

21. Margolis J. Culture and Cultural Entities: Toward a New Unity of Science. Berlin, New York : Springer Science \& Business Media, B.V. 2013. 177 p.

22. McMahon A. M. S. Understanding Language Change. Cambridge : Cambridge University Press, 1994. 361 p.

23. Monier-Williams M. A Sanskrit-English Dictionary: Etymologically and Philologically Arranged with Special Reference to Cognate Indo-European Languages. Köln : Universität zu Köln Institut für Indologie und Tamilistik, 2012. 1333 p. URL : http://www.sanskritlexicon.uni-koeln.de/monier/ (retrieved September 14, 2014).

24. Peregrine P. N., Peiros L, Feldman M. W. Ancient Human Migrations: A Multidisciplinary Approach. Michigan : University of Utah Press, 2009. 208 p.

25. Pereltsvaig A. Languages of the Worlds: An Introduction. Cambridge : Cambridge University Press, 2012. 278 p.

26. Renfrew C., Nettle D. Nostratic: Examining a Linguistic Macrofamily. Cambridge : McDonald Institute for Archaeological Research, University of Cambridge, 1999. 419 p. P. 111.

27. Ross M. C. A History of Old Norse Poetry and Poetics. Cambridge, New York : DS Brewer, 2011. 283 p.

28. Shore B. Culture in Mind: Cognition, Culture, and the Problem of Meaning. Oxford : Oxford University Press, 1998. 448 p.

29. Sratostin S., Starosin G. The Tower of Babel. An Etymological Database. 1998-2013. URL: http://starling.rinet.ru (retrieved May 14, 2014).

30. Sweetser E. From Etymology to Pragmatics: Metaphorical and Cultural Aspects of Semantic Structure. Cambridge: Cambridge University Press, 1998. 175 p. 
31. Swineburne Th. The Coherence of Theism. Oxford : Clarendon Press, 1993. $312 \mathrm{p}$.

32. Trask R. L. Dictionary of Historical and Comparative Linguistics. Chicago, London : Fitzroy Dearborn Publishers, 2000. 403 p.

33. Traugott E. C., Dasher R. B. Regularity in semantic change. Cambridge : Cambridge University Press, 2004. 341 p.

34. Ullmann S. Semantics. Current Trends in linguistics. Vol. 9: Linguistics in Western Europe. Sebeok Th. A., Haugen E., Winter W. (Eds.). The Hague, Paris : Mouton, 1972. P. 343-394.

35. Urban M. Lexical Semantic change and semantic reconstruction. The Routledge Handbook of Historical Linguistics. Bowern C., Evans B. (Eds.). Abingdon : Routledge, 2015. P. 374-392.

36. Wierzbicka A. Semantics : Primes and Universals : Primes and Universals. Oxford : Oxford University Press, 1996. 512 p.

\section{ABBREVIATIONS AND SYMBOLS}

Arm. - Armenian
Av. - Avesta
c - circa / approximately
Cf. - confer
Ch.-K. -
Dag. - Dagur
Dan. - Danish
dial. - dialectal
du. - dual number
Du. - Dutch
Evn. - Evenki
Ger. - German
Gr. - Greek
Hitt. - Hittite
i.e. - id est / that is
ibid. - ibidem / in the same place
Lat. - Latin
Latv. - Latvian
lit. - literally
Lith. - Lithuanian
ME - Modern English
Mid.Kor. - Middle Korean
Norw. - Norwegian

OIr. - Old Irish

Cf. - confer

Ch.-K. -

Dag. - Dagur

OJap. - Old Japanese

ON - Old Norse

Ord. - Ordos

OSax. - Old Saxon

OSw. - Old Swedish

PAlt. - Proto-Altaic

PBalt. - Proto-Baltic

Pers. - Persian

PGmc. - Proto-Germanic

PIE - Proto-Indo-European

PJap. - Proto-Japanese

PKor. - Proto-Korean

PMong. - Proto-Mongolian

PTung. - Proto-Tungus

Sw. - Swedish

Toch. A - Tocharian A

Toch. B - Tocharian B

* - reconstructed form

$<-$ developed from 
OE - Old English

OFris. - Old Frisian

OHG - Old High German

OInd. - Old Indian
$>-$ developed into

$>$ - developed into, derived

from

Information about the author: Kozlova T. O., Doctor of Philological Sciences, Associate Professor, Professor at the English Department,

Zaporizhzhia National University 66, Zukovsky str., Zaporizhzhia, 69600, Ukraine 